ANUARIO DE Estudios Medievales 51/1, enero-junio de 2021, pp. 373-398

ISSN 0066-5061

https://doi.org/10.3989/aem.2021.51.1.12

\title{
LO QUE ANTECEDE AL MADURO Y OPORTUNO PATROCINIO ARTÍSTICO DEL OBISPO LUIS DE ACUÑA (CIRCA 1426-1495)*
}

\section{THE PREVIOUS CIRCUMSTANCES TO THE MATURE AND OPPORTUNE ARTISTIC PATRONAGE OF BISHOP LUIS DE ACUÑA (CIRCA 1426-1495)}

\author{
MARÍA CONCEPCIÓN COSMEN ALONSO \\ Instituto de Estudios Medievales, Universidad de León \\ https://orcid.org/0000-0003-3333-5782
}

Resumen: La figura de Luis de Acuña y Osorio ha sido muy bien valorada, desde finales del siglo $\mathrm{XV}$, por su condición de hombre culto, generoso y gran promotor. Pero estos adjetivos se aplicaban, fundamentalmente, a la última etapa de su trayectoria pública, que transcurrió como obispo de la sede burgalesa. Con este estudio se ha intentado averiguar si el prelado cimentó su posterior fama en su juventud y, sobre todo, durante el desempeño de su cargo en la cátedra de Segovia, el primer puesto relevante de su carrera eclesiástica.

Palabras clave: Segovia; Burgos; obispo; patronazgo; capilla funeraria; ornamentos litúrgicos.

Abstract: The figure of Luis de Acuña y Osorio has been highly regarded since the late $15^{\text {th }}$ century, because of his educated and generous nature, and his figure as a great promoter. However, these qualities essentially apply to the last part of his public life, which he spent as the bishop of Burgos. This study aims to ascertain whether in his youth the prelate laid the foundations for his later fame, primarily during his tenure of the bishopric of Segovia, the first prominent position in his ecclesiastical career.

Keywords: Segovia; Burgos; bishop; patronage; funerary chapel; liturgical ornaments.

\section{SUMARIO}

1. Introducción.-2. Orígenes.-3. Primeros pasos del cursus honorum.-4. Conclusiones.- 5. Bibliografía citada.

* Este estudio se ha elaborado en el marco del Proyecto de Investigación "El Patronazgo artístico en el Reino de Castilla y León (1230-1500). Obispos y Catedrales II" (HAR2017-88045-P), financiado por el Ministerio de Economía, Industria y Competitividad y fondos FEDER.

Citation / Cómo citar este artículo: Cosmen Alonso, María Concepción (2021), Lo que antecede al maduro y oportuno patrocinio artístico del obispo Luis de Acuña (circa 1426 -1495), "Anuario de Estudios Medievales" 51/1, pp. 373-398 https://doi.org/10.3989/aem.2021.51.1.12

Copyright: (C) 2021 CSIC. Este es un artículo de acceso abierto distribuido bajo los términos de la licencia de uso y distribución Creative Commons Reconocimiento 4.0 Internacional (CC BY 4.0). 


\section{INTRODUCCIÓN ${ }^{1}$}

La carrera eclesiástica como obispo de don Luis de Acuña y Osorio se realizó en las sedes castellanas de Segovia, entre 1449-1456, y de Burgos, hasta 1495. La época más desconocida del personaje es su etapa segoviana, pues el patrocinio artístico que llevó a cabo en la caput Castellae, desde su acceso efectivo a la cátedra el 4 de abril de 1457 hasta su muerte el 14 de septiembre de 1495, ha sido mucho más estudiado gracias a las investigaciones históricas y artísticas que se han realizado sobre el siglo XV burgalés ${ }^{2}$. Además, la conservación del testamento del mitrado ha facilitado el acercamiento a las obras que potenció y a los bienes artísticos que acumuló ${ }^{3}$.

Por lo tanto, el perfil de Acuña, que ya se conoció perfectamente, entre los ilustrados, a finales del siglo XV, fue el que escribió Lucio Marineo Sículo en De Hispaniae laudibus:

destacaba por encima de los hombres ilustres de su época (...) espléndido en su generosidad y magnánimo, y sabio en el mundo de las letras. Por ello, habiendo sido enterrado su cuerpo hace poco en una capilla que él había mandado construir en la catedral de Burgos, todos consideraban que su alma ha sido elevada al cielo ${ }^{4}$.

La llegada de don Luis a Burgos la realizó rodeado de un abultado séquito que no tenía dónde instalarse, pues el palacio episcopal estaba en obras, por lo cual el prelado solicitó al cabildo el uso del sobreclaustro, el pontido y el palacio de la Llana ${ }^{5}$. Esta entrada triunfal en la ciudad indica la

\footnotetext{
${ }^{1}$ Abreviaturas utilizadas: ACSg $=$ Archivo Catedral de Segovia; $\mathrm{ACB}=$ Archivo Catedral de Burgos.

${ }^{2}$ López 1961, p. 191; Martínez 1874, pp. 171-175; Eubel 1914, p. 112. El ascenso a Burgos no fue fácil, pues en la carta de pago del Vaticano se indicaba que debía reservar una pensión anual de 100.000 maravedís castellanos para el obispo de Mondoñedo Alfonso Vázquez de Acuña, a instancias de rey Enrique IV (1454-1474). La aspiración de ambos Acuña a la silla burgalesa se pactó de este modo y el mitrado mindoniense pasó a la cátedra de Jaén en 1457. La trayectoria de don Luis se puede ver en: Bartolomé 2004, pp. 79-121, 311,315, 316, 318; Nieto 1993, p. 420; Cendón 2008; Agúndez 2014, pp. 665-687. Con el fin de no incluir listados interminables de bibliografía históricoartística, remito a dos trabajos que la recogen hasta 2013: Andrés 2008, pp. 217-259; Olivares 2013, pp. 21, 33-34, 48-60, 126, 140, 168, 171-177. Las investigaciones más recientes, y las paradigmáticas anteriores, se irán citando en su lugar, así como las obras referidas a Segovia.

${ }^{3} \mathrm{El}$ testamento fue dictado el 12 y 13 de septiembre de 1495 y se conserva en el ACB, Libro, 39/2, ff. 448r-451v, véase su trascripción completa en López 1961, pp. 312-317.

${ }^{4}$ Beltrán 1971, p. 154.

${ }^{5}$ Las obras del palacio episcopal las había iniciado su antecesor Alonso de Cartagena (14351456): Pampliega 2005, p. 38. El palacio de la Llana se encontraba en el casco antiguo, al noreste de la catedral, junto a San Lorenzo: Ruiz 1990, p. 91. El sobreclaustro, que el Colegio de canónigos le dejó utilizar desde el 7 de abril de 1457, va a acoger a servidores del prelado, capellanes, cantores, criados, trojero, escuderos e incluso un laboratorio de alquimia: Pampliega 2005,
} 
importancia del personaje y del cargo que va a ocupar, una situación difícil de improvisar, por lo que es indudable que su posición en Segovia había sido muy preeminente. No obstante, este traslado suponía una mejora evidente a nivel de relevancia de la cátedra y de sus rentas, que pasarían a alcanzar anualmente los 7.200 florines de oro de la Cámara Apostólica ${ }^{6}$. Con esta favorable situación, la pléyade de familiares, clérigos y servidores, algunos llegados desde el anterior destino, como su secretario, Fernando Díaz de Fuentepelayo, fueron ocupando puestos en el cabildo y diócesis burgalesa, así como en el gobierno de la ciudad; este entramado de deudos ayudaría al prelado a cosechar los éxitos que pudo conseguir en esta nueva etapa ${ }^{7}$.

Por otra parte, el obispo continuaba ocupando puestos en la Corte, pues en 1458 se sabe que era Oidor Presidente de la Audiencia Real y se le citaba, también, como Capellán mayor de Enrique IV $^{8}$.

A pesar de esta situación, aparentemente favorable, los primeros 20 años del prelado en Burgos, desde 1457 a 1477, fueron difíciles por la inestabilidad económica y política, a la que se unieron brotes de peste; no obstante, la mesa episcopal no dejó de colaborar con los más necesitados ${ }^{9}$. En este contexto, Acuña, además, tomó partido por el infante Alfonso frente al monarca, o por la infanta Juana frente a Isabel, como lo estaban haciendo, entre otros, sus poderosos familiares de ascendencia portuguesa ${ }^{10}$. Pero, para evitar peligrosos enfrentamientos con los reyes, su habitual salida era retirarse a la villa episcopal de Rabé de las Calzadas, hasta que, en 1481, tras los indultos promulgados por los Reyes Católicos, regresó definitivamente a la capital ${ }^{11}$.

pp. 29-30, 33-39. El pontido fue un asunto de debate cabildo-obispo, pues los canónigos no querían perder competencias sobre dicha estructura. Desde 1488 se sentencia su demolición, que se hará en 1579: López 1961, pp. 191-192; Agúndez 2014, pp. 668; Pampliega 2005, pp. 12, 30.

${ }^{6}$ Eubel 1914, p. 112.

${ }^{7}$ Respecto a sus medio-hermanos, Antonio Sarmiento llegó a ser regidor de la ciudad y Pedro Girón, eclesiástico, alcanzó el arcedianato de Valpuesta: Miñano 1827, p. 467; López 1961, pp. 196-197, 282; Atienza 2008, p. 369. En la documentación del ACB se ve la importancia del grupo que rodeaba al prelado y que, desde 1457 hasta su muerte en 1495, se integró en la vida de la Iglesia burgalesa desde todas las áreas de actuación. Así, se nombra a la madre, hermanos, hijos, sobrinos, fiscal, secretario, escuderos, despensero, mayordomo, criados o al mismo obispo, cuando debe pagar por las honras fúnebres de su madre, en 1465: López 1961, pp. 200, 312-317; Agúndez 2014, pp. 683-684.

${ }^{8}$ Nieto 1993, p. 178; Cañas 2012, p. 221.

${ }^{9}$ López 1961, pp. 207-220; Ladero 2008, pp. 79-89; Asenjo 2008, pp. 175-197; Nieto 2008, pp. 221-234.

${ }^{10}$ La Crónica de Enrique IV señala que "el obispo don Luis de Acuña fue uno de los grandes que aprobaron la sublimación del rey don Alonso": Rosell 1875-1878, vol. III, cap. XXX, p. 34; López 1961, p. 268; Nieto 1993, pp. 277-283, 287; Díaz 2013a, pp. 145, 155; 2013b, pp. 200-201; Franco 2014, pp. 68, 83, 94, 158.

${ }^{11}$ La población, situada a unos $11 \mathrm{~km}$ al oeste de la capital, tenía una fortaleza episcopal que hoy ha desaparecido. En ese recinto, que también ayudó a mejorar arquitectónicamente, buscó 
Aunque los problemas no eran menores, el prelado gobernó y defendió la diócesis ante el rey y el papado, con sus imposiciones recaudatorias excesivas, y frente al cabildo, que mantenía posturas poco reformadoras ${ }^{12}$. El sínodo burgalés de 1474 incidió en la organización, obligaciones, decoro y buen funcionamiento del clero, pero sin olvidar su adecuada preparación, por lo que el obispo apoyó a la escuela de gramática, que dependía del cabildo, y se impuso el examen previo a la recepción de las órdenes sagradas. Además, se aclaró el papel de los arciprestes en cuanto a las visitas, reparación y ornato de las iglesias a su cargo ${ }^{13}$. Acuña llegó a varias concordias con el cabildo en asuntos de jurisdicción, provisión de prebendas y administración de la fábrica, y su papel como reformador lo llevó a colaborar en esta tarea con varios monasterios y a acercarse a franciscanos y dominicos ${ }^{14}$. La relación que mantuvo con estos últimos en San Pablo de Burgos fue muy estrecha y ellos le ayudaron, espiritual y materialmente, por ejemplo, prestándole capas, en 1463, para las celebraciones litúrgicas en la catedral. Incluso, entregó su testamento al prior, Fray Alonso de Aguilar, a quien le encargó su ejecución ${ }^{15}$.

Por lo que respecta al patrocinio artístico de don Luis en la catedral burgalesa, que, o bien está documentado, o bien muestra sus blasones, se inició con obras heredadas de su predecesor Alonso de Cartagena (1435-1456). Me refiero, en primer lugar, a la aguja de la torre norte de la fachada occidental, que llevó a cabo Juan de Colonia hasta 1458, y donde se conservan las armas de Acuña ${ }^{16}$. También se atribuye al mismo maestro el cimborrio, que

refugio el prelado en momentos complicados: López 1961, p. 229; Rodríguez 2002, p. 721; Pampliega 2005, p. 39.

${ }^{12}$ López 1961, pp. 233-245; Por otra parte, el rey hacía un uso incorrecto de las tercias reales, distribuyéndolas, cada 20 años, entre las fábricas de las iglesias y la Cámara Apostólica; por ello, Paulo II, en 1470, ordenó al arzobispo de Sevilla y a los obispos de Sigüenza y Burgos que abriesen los procesos correspondientes: Nieto 1993, pp. 79-82, 321-322.

${ }^{13}$ Martínez 1874, p. 172; López 1961, pp. 246-261; 1966, pp. 331-357; Aldea, Marín, Vives 1972, vol. I, p. 8; García 1997, pp. 31-32; Bartolomé 2004, pp. 119, 316; Guijarro 2018, pp. 23-24.

${ }^{14}$ López 1961, pp. 216, 220, 280-283. La reforma franciscana, en los años sesenta, estuvo salvaguardada por el arzobispo de Toledo y los obispos de Córdoba y Burgos: Nieto 1993, p. 396. El prelado apoyó, en esta línea, a los frailes de San Esteban de los Olmos, en las afueras de la capital burgalesa, donde su madre y medio-hermanos localizaron su panteón. El sepulcro de la progenitora $(\dagger 1465)$ se conserva hoy en el Museo Provincial de Burgos y es una interesante obra, pero no se conoce si la patrocinó el obispo: Agúndez 2014, p. 676.

${ }^{15}$ López 1961, p. 282.

${ }^{16}$ Se remataron las torres desde 1442 y el Concejo colaboró con 10.000 maravedís, según se señaló en el cuaderno de Memorias Funerarias de la Capilla de la Visitación: Martínez 1866, pp. 19-22; 1874, p. 174; López 1961, p. 280; López Mata 1966, pp. 45, 48; Payo 2008, pp. 218, 219, 221; Menéndez 2009, p. 150; 2010, p. 334; Olivares 2013, p.33; Payo, Martín 2018, pp. 141-143. El escudo del obispo es cuartelado, en el primer cuartel, sobre campo de plata, aparece una banda con cruz floreteada y cuñas en los extremos, que, en su perímetro, muestra cinco escudetes con cinco besantes de plata. En el segundo cuartel, una mano -con su 
estaba en construcción en 1465 y se hundió en 1539; obra, para la que, dadas las dimensiones del proyecto, el cabildo dedicó todos sus esfuerzos hasta 1471 y el obispo colaboraría con los medios necesarios ${ }^{17}$. Por otra parte, en dos tramos del antepecho del triforio catedralicio también campean los escudos de nuestro obispo, uno, en el cuarto tramo del cuerpo del templo, sobre el coro, y otro, en el cierre oriental del brazo norte del crucero ${ }^{18}$.

De lo que sí hay constancia documental es de una de las obras de platería que promovió el prelado, me refiero a la mejora de la imagen de Santa María la Mayor del retablo principal. Acuña manifestó al cabildo, en 1460, su deseo de hacerla de mayor tamaño, para lo que destinó la plata necesaria y los canónigos contribuyeron con 10000 maravedís $^{19}$. En 1464 la figura estaba terminada y el trabajo pudo deberse a Cristóbal de Valladolid, que aparece en la documentación como platero del obispo; además, la imagen recibió, en 1488, una corona ${ }^{20}$. Don Luis encargó, también, tres relicarios con forma de estatuillas de plata sobredorada con las figuras de los apóstoles Pedro, Pablo y Santiago. Todos ellos llevan las armas del comitente en sus respectivas peanas $\mathrm{y}$, aunque no se tienen más datos sobre el encargo que las marcas del interior del pie del último santo citado, las señales que allí se estamparon advierten de su procedencia burgalesa ${ }^{21}$.

Otro trabajo destacado, que lleva los escudos del obispo, es el realizado para los batientes de madera de la portada que comunica la catedral con el claustro. Las piezas, con relieves de la entrada de Cristo en Jerusalén y la Anástasis, más las figuras sedentes de san Pedro y san Pablo, han sido atribuidas a Gil de Siloe y, posiblemente, fueron talladas en los años 90 del siglo $\mathrm{XV}^{22}$.

Además de todo lo anterior, el encargo más sobresaliente-entre los conservados- que mandó hacer don Luis de Acuña fue la Capilla de la Concepción,

manga- sujeta una espada sobre campo de gules. En el tercer cuartel, de plata, se efigia un león rampante y en el cuarto, de oro, se colocan dos lobos pasantes.

${ }^{17}$ Payo, Matesanz 2013, pp. 21-35.

${ }^{18}$ Aún no se ha hallado documentación para dichos trabajos, que se suelen fechar a fines del siglo XV: López Mata 1966, p. 49.

${ }^{19}$ Barrón 1998, pp. 189-190.

${ }^{20}$ Martínez 1886, pp. 40-42; López Mata 1966, p. 96; Barrón 1998, p. 190. A la imagen aludió, en 1465, León de Rosmithal y dijo que pesaba 300 marcos de plata y que su hechura valía otro tanto, García 1999, p. 247.

${ }^{21}$ López Mata 1966 p. 350; Barrón 1998, p. 191. El doctor Barrón propone para su hechura entre 1465 y 1472. Además, en la figura de Santiago vio la marca de Burgos y un punzón con las letras IF en un escudete. Las iniciales pueden ser las del marcador Juan García de Frías, documentado entre 1483 y 1488: Bango 2001, pp. 413-414; Negro 2008, p. 482. Actualmente, los fenotipos característicos de Pedro y Pablo no se corresponden con los símbolos parlantes que portan, es posible que en alguna restauración se intercambiasen.

${ }^{22}$ No se ha encontrado, aún, documentación específica: Martínez 1866, pp. 134-135; López Mata 1966, p. 194; Yarza 2000, p. 25; Andrés 2008, pp. 253, 258. 
que se ubicó en el ángulo formado por el brazo norte del transepto catedralicio y la nave del evangelio. La obra y su ornato supusieron un gasto enorme, millón $\mathrm{y}$ medio de maravedís, y se le asignó una función funeraria ${ }^{23}$. La construcción, con permiso del cabildo, se comenzó a preparar en 1477 y en 1492 sólo faltaban por poner los costados del retablo, aunque, desde 1488, Acuña ordenó el servicio y sus estatutos ${ }^{24}$. Los maestros Juan y Simón de Colonia debieron realizar la arquitectura, con planta irregular, adaptada al espacio disponible, y altas bóvedas estrelladas y pintadas; Gil de Siloe y su taller hicieron el destacado retablo tallado que policromó Diego de la Cruz; el tema central es el Árbol de Jesé, señalando la estirpe de María, al que se unen, en segundo plano, la figura del Obispo y su santo protector san Huberto ${ }^{25}$. La portada de acceso al recinto es un amplio y sencillo vano policromado, con doble arquería que está moldurada y decorada con motivos vegetales y cuatro pequeñas figuras (Sansón y Santiago, entre ellas). La reja que lo cierra está documentada, la realizó Luis de Paredes circa 1485 y en ella se muestran las armas del prelado soportadas por dos grifos ${ }^{26}$.

En este periodo de obras en su capilla, don Luis planificó un nuevo palacio episcopal en la misma plaza de la catedral, pero separado del templo; pensaba derribar el viejo y las casas de la cerería, con el fin de despejar la iglesia hasta la puerta del Sarmental. Aunque se buscó el acuerdo en el cabildo, el 17 de junio de 1486, la idea no se llevó a cabo y Acuña solo pudo hacer ciertas obras en el palacio antiguo ${ }^{27}$.

Por lo que se refiere al sepulcro del prelado, las indicaciones que dejó en su testamento para su realización, aunque no al pie de la letra, se llevaron a cabo años más tarde, cuando sus testamentarios encargaron a Diego de Siloe, en 1519 , la obra. Un bello trabajo, totalmente renacentista, que sigue ocupando el centro de la capilla funeraria ${ }^{28}$.

${ }^{23}$ Martínez 1866, pp. 127-131; López Mata 1966, pp. 291-302, este autor anotó que el clérigo Atienza vio pagar al "maestre Gil padre" los dineros del retablo. López 1961, pp. 277-280, asegura que las sumas las especificaba el obispo en 1492; Andrés 2008, pp. 228-230; Olivares 2013, pp. 50-56.

${ }^{24}$ Martínez 1866, pp. 127-131, 208; López 1961, pp. 277-278; López Mata 1966, pp. 291-298.

${ }^{25}$ López 1961, pp. 227, 277, 280; López Mata 1966, pp. 294-295, 298, 403; Yarza 2000, pp. 13, 24, 33-46, 198; Andrés 2008, pp. 230-234; Olivares 2013, pp. 50-52. El tema de San Huberto ha sido aclarado por Gómez 1994, pp. 422-425. Nicolás López señaló que el obispo era aficionado a la equitación y la caza, como en su testamento queda patente: López 1961, pp.192-193, 315; Yarza 2000, pp. 146-151; Villaseñor 2017. Está claro que el tema de San Huberto, noble, cazador y obispo, era adecuado para don Luis e introducía un motivo iconográfico novedoso en la catedral: Réau 1997, pp. 90-95.

${ }^{26}$ Martínez 1866, p. 129; López 1961, p. 278; López Mata 1966, p. 295.

${ }^{27}$ Martínez 1866, pp. 164, 174; López 1961, p. 280; López Mata 1966, pp. 442-445; Olivares 2013, pp. 58-59.

${ }^{28}$ Martínez 1866, pp. 130-131, 288-289, aquí se copió el contrato del sepulcro con todos los detalles de materiales y decoración al romano e incluso la forma de pago. Además, López 1961, 
Según consta en el Códice 28 de los obituarios de la catedral de Burgos, un acuerdo del cabildo, del 28 de enero de 1506, lo obliga a decir, anual y perpetuamente, seis memorias especiales por el alma del señor obispo Luis de Acuña, en días perfectamente especificados. En esas ceremonias los canónigos debían sacar las capas de seda carmesí aceituní que les donó el obispo ${ }^{29}$. También, en relación con otras piezas textiles, existe una noticia de la catedral burgalesa, fechada en un inventario de 1560, donde se decía que tenían 11 tapices dorados y brocados que llamaban del obispo don Luis ${ }^{30}$.

Fuera del complejo catedralicio, el prelado apoyó a otras instituciones como al convento de la Bretonera (Belorado, Burgos), que fue reformado con su ayuda y, además, se hizo cargo de la construcción del dormitorio principal de las monjas; en su testamento, les encargó oraciones y les dio dinero para pitanza ${ }^{31}$.

Por último, se debe destacar la magnífica biblioteca que don Luis legó a su hijo Diego Osorio, con 363 volúmenes y de la que se conserva un inventario de 1496. Muchos de los libros trataban de asuntos jurídicos, preferentemente obras italianas de los siglos XIII al XV ${ }^{32}$. Entre los ejemplares había un Ordinario rico luminado, con sus manos de plata, y una Biblia en pergamino con su caja ${ }^{33}$. Además, se han conservado tres manuscritos, iluminados con formas estilísticas tradicionales, que salieron del patrocinio de Acuña, un Pontifical, las Constituciones de la Capilla de la Concepción y la Regla de la Cofradía de la Creación, trabajos que han sido estudiados en varias ocasiones $^{34}$. Para cerrar el asunto librario, tenemos noticias documentales de un misal grande, de pergamino con letras doradas, y ricamente encuadernado en plata, donde se representó, en una de las cubiertas, la Asunción de María y, en la otra, la Crucifixión, amén de las armas -doradas- del obispo Acuña ${ }^{35}$.

p. 280; López Mata 1966, pp. 301, 404; Andrés 2008, pp. 235-236; Olivares 2013, pp. 55-56; Vasallo 2018, pp. 8-9.

${ }^{29}$ Serna 2008, pp. 132-134. El racionero Angulo en 1551 alude a 40 capas donadas por el obispo Acuña con sus armas: Martínez 1874, p. 174; López 1966, p. 353.

${ }^{30}$ López 1966, p. 353.

${ }^{31}$ López, 1961, pp. 280, 313.

${ }^{32}$ Salvador 2008b, p. 68; 2008a, p. 256.

${ }^{33}$ López 1960, pp. 81-110.

${ }^{34}$ Para la bibliografía específica sobre la miniatura de estas obras: López-Mayán 2012; Villaseñor 2017; Pazos 2018; Úzquiza 2017; Guijarro 2018; López-Mayán 2019. Por otra parte, el texto para la cofradía de la Creación fue fechado en 1494 y se había adscrito al entorno de don Luis de Acuña, pues intervino en la reforma y aprobación de estos estatutos, que se hicieron sobre la base de otra regla que tenía más de 200 años de existencia: Mansilla 1952, p. 89, quien dice, "en el último folio hay una Adoración de los Reyes. La N inicial en azul con dibujos en blanco, enmarcada en oro, tiene en el interior la figura de un obispo de pontifical, que bien pudiera ser don Luis de Acuña".

${ }^{35}$ Ibidem, pp. 187-191. 
Este abrumador elenco de noticias relacionadas con las actuaciones del prelado y su patrocinio artístico, desde la cátedra en la caput Castellae, convirtió al obispo Acuña en el personaje eminente del que hemos hablado al principio. Las rentas, posición, madurez y circunstancias, hicieron posible la materialización de sus ideas patrocinadoras, las cuales contaron también con la colaboración del cabildo y de la ciudad, donde tenía el apoyo de sus deudos.

\section{ORÍGENES}

La explicación de la magnificencia patrocinadora desplegada por el prelado en Burgos, intentaremos fundamentarla a través del conocimiento de su vida anterior.

Desafortunadamente, no se sabe el momento y lugar exactos de su nacimiento, pero cuando don Luis fue promovido a la diócesis de Segovia, en 1449, tenía solo 23 años, tal y como apareció reflejado en los Registros de la Cámara Apostólica Vaticana ${ }^{36}$. Por lo tanto, es posible que hubiese nacido en torno a 1426.

Sus padres fueron Juan Álvarez Osorio, señor de Villastugo, vecino de Palencia $(\uparrow 1436)$ y María Manuel Acuña $(† 1465)$, quien le trasmitió el apellido que utilizaría en primer lugar ${ }^{37}$. Esta dama, miembro de una rama portuguesa de los da Cunha, contó con unos destacados progenitores, Sancho Manuel, descendiente del rey Alfonso X, y doña Ginebra de Acuña ${ }^{38}$.

Este entronque luso, por línea femenina, los unía a Martín Vázquez da Cunha, uno de los grandes personajes en la etapa de acceso al poder de Juan I de Avis (1383-1433) ${ }^{39}$. El noble citado fue cabeza de la facción que en

${ }^{36}$ Eubel 1914, p. 234. Los datos se han extraído del Archivo Apostólico Vaticano, Cámara Apostólica, Obligationes et Solutiones, libro LXXII, f. 36, con fecha de 7 de abril de 1449. Agradezco al Doctor Santiago Domínguez su ayuda en relación con las cuestiones que tienen que ver con documentación latina.

${ }^{37}$ La confusión en relación con el padre del prelado fue muy común y se le solía hacer hijo de Pedro Álvarez Osorio, primer conde de Trastámara. Nicolás López Martínez aclaró la cuestión definitivamente y así aparece en estudios recientes: López 1961, pp. 194-196; Agúndez 2014, pp. 665-687.

${ }^{38}$ Morais, et al. 1943 , p. 458.

${ }^{39}$ Quiero expresar mi agradecimiento a la documentalista y asistentes de la biblioteca de la Facultad de Filosofía y Letras de la Universidad de Coímbra, por su inestimable ayuda a la hora de acceder a las fuentes y bibliografía más pertinente para estudiar a la familia Acuña desde sus orígenes.

La estirpe aludida tuvo su solar en el norte de Portugal y empezó a prosperar desde su acercamiento a la corte del monarca Afonso Henríquez (1139-1185), quien ya les concedió privilegios. De aquella etapa inicial se conoce el detalle de la destrucción de la torre nobiliaria del solar da Cunha, antes de 1210, por parte del monarca Sancho I (1185-1211). Durante los siglos XIII y XIV, sus posesiones aumentaron y se expandieron a las zonas a repoblar de Beira, 
las Cortes de Coímbra, de 1385, contradijo la elección del nuevo rey; como resultado, y tras ser amenazado de muerte por Nuno Alvares Pereira, jefe de la oposición vencedora, se desnaturalizó y pasó a Castilla en $1397^{40}$.

$\mathrm{Al}$ instalarse en el reino vecino, fue nombrado por Enrique III (13901406) conde de Valencia de Campos, la actual Valencia de don Juan ${ }^{41}$. Esta nueva situación lo hizo recuperar su preeminente estatus y pudo casar a su hija Ginebra con Sancho Manuel, progenitores de María Manuel Acuña. Esta dama contrajo primeras nupcias con Juan Álvarez Osorio del que tuvo, al menos, tres hijos, Inés de Osorio, Alvar Pérez Osorio y Luis de Acuña ${ }^{42}$.

La hermana del futuro prelado, Inés, señora de Abarca, fue una relevante promotora palentina. Se la conoce por el apoyo que dio a las obras del crucero de la catedral de su ciudad y por la contribución al enriquecimiento del ajuar litúrgico de la misma; el templo mayor fue, además, el lugar que eligió para recibir sepultura ${ }^{43}$.

Por lo que se refiere al hermano del obispo, este lo menciona indirectamente en su testamento, pues dejó escrito que debía a su sobrina, hija de Alvar, los 100.000 maravedís que le prometió para su boda ${ }^{44}$.

a enclaves próximos a Coímbra e incluso a las cercanías de Lisboa. Un miembro de esta familia fue Juan Lorenzo da Cunha, casado con Leonor Téllez, que pasará a ser la esposa de Fernando I de Portugal (1367-1383). A la muerte de este monarca, los problemas de sucesión hacen salir a la palestra a Martín Vázquez da Cunha, que se colocó en el bando que defendía la herencia al trono portugués de la infanta Beatriz, casada con Juan I de Castilla (1379-1390), véanse, Lopes 1966 pp. 153-155; Pimenta 1983, pp. 52-54, 83; Mattoso 1985, p. 150; Sotto Mayor 1999, vol. II, pp. 347, 349; Oliveira 2013, para la crisis de 1384-1385: pp. 381-399.

${ }^{40}$ Lopes 1973, pp. 360-362; Morais, et al. 1943, pp. 457-458. El asunto de las familias portuguesas que se exilian a Castilla en el siglo XIV ha sido tratado en reiteradas ocasiones, algunos ejemplos significativos pueden ser: Baquero 1973, pp. 85-87; Romero 2002, vol. I, pp. 531-533; Suárez 2003, pp. 140-148, 369-372.

${ }^{41}$ Vázquez da Cunha tuvo de su segunda esposa, Brites de Portugal, nieta de Pedro I (13571367), a Ginebra da Cunha, abuela de nuestro prelado: Morais, et al. 1943, p. 458.

${ }^{42}$ Tal y como se rastrea en la documentación de la catedral de Palencia, Juan Álvarez Osorio se debió de casar en segundas nupcias con María Manuel, pues el cabildo palentino, en 1424, y, de nuevo, en 1437, reclama la legítima que le corresponde, de la que suponemos, primera mujer de Osorio. Por otra parte, doña María, en 1463, tuvo contactos con la citada institución a causa de las rentas de una aceña y se la denomina "madre del obispo de Burgos", véase Francia 1989a, docs. 237, 608, 2739. De un segundo matrimonio con García Sarmiento, la madre del obispo tuvo a Antonio Sarmiento y Pedro Girón, que destacarán en Burgos: Agúndez 2014, p. 676.

${ }^{43}$ Las relaciones y donaciones que hizo doña Inés de Osorio al cabildo palentino, materializadas incluso después de su fallecimiento, se rastrean en las Actas capitulares de dicha institución durante los años 1460, 1462, 1493, 1494, 1495 y 1500, véanse Francia 1989b, docs. 4694, 4705, 4726, 4747, 4668, 4784, 4979, 5055, 5230, 5269; Martínez 2011, pp. 241, 275, 276; Castro 2000, p. 45. En las claves de cuatro tramos del crucero catedralicio hay escudos de Inés Osorio, dos lobos pasantes y seis roeles de oro y, además, se conoce que donó capas de damasco blanco y un retablo de plata. Doña Inés murió en 1492 y se conserva el bello monumento funerario que encargó, tallado en madera por Alonso del Portillo: Ara, 1987, pp. 231-232; 2001, pp. 171-173.

${ }^{44}$ López 1961, p. 195. 
En cuanto a don Luis de Acuña, desconocemos aún el principio de su vida pública y no tenemos noticias de su formación ${ }^{45}$. Desde luego sus estudios, si se llevaron a cabo, no fueron realizados en la Universidad de Salamanca, donde su nombre no se rastrea en los diplomas y actas catedralicias, tampoco aparece en el Bulario de la institución universitaria, ni entre los colegiales de San Bartolomé; únicamente Beltrán de Heredia lo cita, una sola vez, en los índices del Cartulario de la Universidad, pero ya como obispo de Burgos. Tampoco aparece su nombre entre los estudiantes de San Clemente de Bolonia, aunque la relación con esa institución sí la mantuvo más tarde, cuando, como mitrado burgalés, pudo presentar aspirantes que deseaban estudiar en ese centro ${ }^{46}$.

Por otra parte, aunque reiteradamente se menciona su matrimonio de juventud con Aldonza de Guzmán y su posterior entrada en la Iglesia, no se ha podido comprobar tal situación, aunque sí está claro que tuvo varios hijos. Uno de ellos fue Diego de Osorio, heredero de su tía Inés, quien llegó a ser regidor de Burgos en 1480 y caballero de la Cofradía de Santiago de la Fuente, a la cual pertenecía aún en $1531^{47}$.

Otro de los vástagos del prelado fue Antonio de Acuña, obispo de Zamora en 1507, dignidad que alcanzó tras hacer estudios en Roma y haber disfrutado de prebendas en la diócesis de Burgos, donde fue canónigo y posteriormente arcediano, al morir Fernán Díaz de Fuentepelayo, mano derecha de su padre ${ }^{48}$. Se conoce, además, que formó parte de la Orden Militar de Calatrava y que la trayectoria final de su vida estuvo marcada por la activa participación en la guerra de las Comunidades, lo que le condujo a la muerte en Simancas, en el año $1526^{49}$.

La situación que se acaba de describir se hizo oficial cuando el papa Alejandro VI, en 1493, concedió a don Luis la facultad de testar a favor de sus dos hijos Diego y Antonio ${ }^{50}$.

Por otra parte, tampoco se debe olvidar que, en el segundo tercio del siglo $\mathrm{XV}$, algunos familiares del prelado alcanzaron unas cotas de notoriedad

\footnotetext{
${ }^{45}$ Caso nada extraño en el siglo XV, como se ha podido comprobar para los embajadores de los reyes, entre los que se encontraba don Luis de Acuña, véase Villarroel 2010, p. 811.

${ }^{46}$ Bertrán 1981.

${ }^{47}$ López 1961, p. 201. A Diego también se le rastrea en Palencia, como heredero de la aceña de su madre María Manuel. El cabildo palentino, en 1465 y 1484, intentó aclarar con él los derechos sobre esta instalación: Francia 1989a, doc. 2916; 1989b, doc. 4461.

${ }^{48}$ López 1961, p. 199; Agúndez 2014, p. 669, n. 10.

${ }^{49}$ López 1961, p. 202; Aldea, et al. 1972, vol. I, p. 7. Una dama, Teresa de Guzmán, pudo formar parte de la descendencia del obispo, pero, hasta el momento, faltan datos específicos que lo sostengan, Bartolomé 2004, p. 119.

${ }^{50}$ López 1961, p. 20.
} 
enormes en el reino de Castilla. Su parentesco con Pedro Girón (†1466), señor de Belmonte, Juan Pacheco, marqués de Villena (†1474) y el arzobispo de Toledo Alfonso Carrillo de Acuña (†1482), lo llevará a situaciones comprometidas en los años convulsos que le tocó vivir ${ }^{51}$.

\section{PRIMEROS PASOS DEL CURSUS HONORUM}

Como hemos adelantado, poco sabemos de la trayectoria de nuestro personaje antes de acceder al obispado de Segovia, en 1449. Parece ser que en aquellos momentos era canónigo de dicha sede y arcediano de Valpuesta, en Burgos ${ }^{52}$; con ese bagaje, será presentado por el rey Juan II (1406-1454) para ocupar la silla episcopal castellana, aunque, como era demasiado joven para ser consagrado, pues tenía 23 años, se le nombró administrador ${ }^{53}$. Será en la década siguiente cuando se le rastree, además, como Canciller Mayor de Blanca de Navarra, princesa de Asturias, recibiendo, por ello, 34.000 maravedís, librados en $1453^{54}$. Por lo tanto, como era habitual en aquellos momentos, su dedicación a la Iglesia se alternaba con tareas adscritas a la Corte.

La permanencia del prelado en la cátedra segoviana se dilató hasta fines de 1456, por lo tanto, fueron siete años al frente de este episcopado, de los que dejó un rastro sutil. Respecto a su papel como promotor, tampoco tenemos evidencias muy llamativas, pero sí las suficientes señales de una labor callada, que llevó a cabo en aquellos años en los que se estaba luchando por mejorar el centro catedralicio y construir otras instalaciones religiosas, entre las que destacó, por ejemplo, el monasterio de El Parral ${ }^{55}$.

En los textos conservados de la diócesis se menciona al obispo con respeto, como persona eminente y regia, que disfrutaba del $16 \%$ de los diezmos más los rendimientos de propiedades y derechos señoriales adscritos a la mitra ${ }^{56}$. Las rentas anuales de don Luis, desde 1449 hasta 1456, tanto siendo administrador como obispo, ascendían a 3.990 florines de oro de la Cámara Apostólica ${ }^{57}$.

\footnotetext{
${ }^{51}$ Agúndez 2014, p. 668; Franco 2014.

${ }^{52}$ Cañas 2012, p. 221.

${ }^{53}$ Eubel 1914, p. 234, donde se dice que Ludovicus Vasci de Acugna et Osorio prometió pagar el tributo del "servicio común", que abonaban todos los nuevos obispos y abades exentos, el 7 de abril de 1449.

${ }^{54}$ Cañas 2012, p. 221.

${ }^{55}$ Enrique IV (1454-1474) y el marqués de Villena, Juan Pacheco, personajes muy próximos al obispo, lograron apoyar a los jerónimos y comenzar las obras a partir de 1454, véase Barrio 2004, pp. 431, 595; López 2006, pp. 198-200.

${ }^{56}$ Colmenares 1846, p. 269; Sanz 1967, p. 183; Barrio 2004, pp. 399, 404.

${ }^{57}$ Eubel 1914, p. 234; el florín citado equivalía a 3,537 gr. de oro.
} 
Como tarea primordial de este periodo, se señala que fue don Luis el encargado de pronunciar, el día 11 de mayo de 1453, en la iglesia de San Pedro de Alcazarén (Valladolid), lugar que dependía desde 1140 del episcopado segoviano, la sentencia de invalidación del matrimonio entre el príncipe Enrique y Blanca de Navarra $^{58}$. En este documento, aparece citado el prelado como administrador, pero dos meses después, el 27 de julio, cuando se presentaron ante Gonzalo Gómez, chantre, juez y vicario de la Iglesia de Segovia, las cartas de aceptación de la sentencia por parte de doña Blanca, Acuña ya era obispo ${ }^{59}$. Por lo tanto, con tal título asistiría a los funerales de Juan II en $1454^{60}$.

Por otra parte, dentro de la década de los años 50 del siglo XV, en la documentación conservada en los archivos catedralicio y diocesano de Segovia, aunque las citas a Luis de Acuña no son demasiadas, se le rastrea en varios diplomas. Por ejemplo, en 1449 y 1452 defiende los intereses de los canónigos frente a Pedro de Luna, señor de Fuentidueña, quien impedía sacar de esa villa los frutos de los diezmos y heredades de los prebendados ${ }^{61}$. En otros dos documentos de 1450, se especificaron ciertos problemas entre los concejos de Segovia y de la villa episcopal de Turégano; asuntos referidos a límites de tierras, que se solucionaron, con la intervención del prelado, a favor del lugar diocesano ${ }^{62}$. Además, otro diploma firmado por don Luis Dacunna en sus palacios, el 25 de diciembre de 1451, recoge una permuta entre la diócesis segoviana y Diego Arias de Ávila, contador mayor del príncipe Enrique, a cambio de 3.000 maravedís anuales, de las rentas de las alcabalas de la villa de Fuentepelayo ${ }^{63}$. Este asunto será confirmado por Enrique IV (1454-1474) en 1456 y $1459^{64}$. Por último, el 16 de enero de 1456, Acuña aparece firmando un documento del mismo monarca sobre aprovechamiento de tierras entre los concejos de Mojados, Olmedo y Portillo, en el que firma como "electo de la Iglesia de Burgos" ${ }^{65}$.

${ }^{58}$ Colmenares 1846, p. 270; Salvador 2008a, pp. 255-258, 266-67; 2008b, p. 67; Díaz 2015, p. 145.

${ }^{59}$ Salvador 2008a, p. 265. El prelado había alcanzado la edad de 27 años, pero, de momento, desconocemos los detalles de su consagración episcopal.

${ }^{60}$ Colmenares 1846, p. 271.

${ }^{61}$ Sanz 1988, docs. 352, 361.

${ }^{62}$ López, Juárez 2014, docs. 30, 31. Turégano había sido donado por la reina Urraca (11091126) a los obispos de Segovia en 1123 y fue la villa principal del señorío episcopal segoviano hasta 1805, véase Bartolomé 1996, pp. 193, 210, 219. En Turégano se refugió el marqués de Villena, en el año 1450, antes de alcanzar Toledo. El pariente del obispo Acuña había sido acusado ante el rey de cargos gravísimos, pero la relación familiar prevaleció, no sin peligro para el prelado: Borreguero 1991, p. 94; Suárez 2003, pp. 260-261.

${ }^{63}$ López, Juárez 2014, doc. 32. El marco de estas actuaciones se puede ver en Santamaría 1990, pp. 60-67.

${ }^{64}$ Sanz 1988, doc. 378; López, Juárez 2018, doc. 55.

${ }^{65}$ López, Juárez 2014, doc. 33. 
Para concluir su estancia en Segovia, el obispo selló una Concordia con el cabildo el 30 de noviembre de 1456; acuerdo que buscaba hallar paz y sosiego en los negocios de ambos ${ }^{66}$. Por otra parte, no hay constancia de la convocatoria de algún sínodo en este periodo, pero el convenio que acabamos de referir es un claro antecedente de las futuras actuaciones del mitrado, siempre en línea con la reforma y puesta al día de las sedes a su cargo ${ }^{67}$.

Como se ha indicado, las huellas dejadas por don Luis en esta fase son tenues. No obstante, hemos podido advertir la cercanía al príncipe Enrique, al intervenir en la anulación de su matrimonio, y, en cuanto a los asuntos diocesanos, desde luego su papel no parece menor, pues alcanzó soluciones negociadas sobre propiedades, derechos y desarrollo jurisdiccional, tal y como muestra la sucinta información aludida. Todo ello de una importancia capital a la hora de conseguir que las rentas se incrementasen, las prerrogativas se protegiesen y los asuntos internos, que pudieran ser motivo de enfrentamiento entre el obispo y el cabildo, se solucionasen con pactos consensuados. De este modo, es muy posible que la postura de Acuña condujese a su obispado a mejorar la situación económica y organizativa, con lo que puso las bases para emprender otros proyectos, como la mejora del vetusto centro catedralicio.

Por lo que se refiere al núcleo central de nuestra investigación, prácticamente no hay rastro documental de empresas artísticas patrocinadas por Acuña en Segovia, lo que no deja de sorprender a los investigadores, ya que su predecesor en la cátedra, Juan Cervantes (1441-1449), vio la pobreza de la fábrica catedralicia y lo "muy menguada" en ornamentos que estaba ${ }^{68}$.

La penuria de la obra de Santa María, que estaba situada en un solar colindante al flanco meridional del Alcázar de la ciudad, se podría explicar por su antigüedad, pues era una construcción románica, que se continuó en el siglo XIII, y en la que se hicieron arreglos en torno a $1436^{69}$.

${ }^{66}$ Las dignidades que vacasen las proveería el obispo, en meses ordinarios, y el resto el Papa. Se asignarían por turnos las canonjías, raciones y medias raciones. Se señaló cómo debían ascender en el escalafón los prebendados o cómo tenían que efectuarse las destituciones de capellanías, que eran proveídas por el Cabildo, a excepción de la de San Lucas que correspondía al prelado. Se organizaron las deudas sobre contribuciones de los beneficiados y los arrendamientos de los bienes de la Iglesia y sus condiciones: Quintanilla 1954, pp. 320-327; Santamaría 1990, p. 58.

${ }^{67}$ García 1993, pp. 381-423.

${ }^{68}$ Don Juan, en 1447, aconsejó al cabildo el uso del juro de heredad, que recibían de Juan Pacheco, tras la cesión de la ermita de Santa María del Parral, para paliar estas carencias: López 2006, p. 29; La confirmación de este traspaso de rentas, que ascendía a 10.000 maravedís, aparece en una confirmación real de 1456: López, Juárez 2018, doc. 54.

${ }^{69}$ El edificio se consagró en 1228 y 1257: Flórez 1860, p. 89; Lecea 1889, pp. 222-223; Ruiz 1994, p. 162; Cortón 1997, pp. 15-16; López 2006, p. 18. El 8 de junio de 1436, el cabildo y el obispo Juan de Tordesillas (1398-1437) refirieron que estaba en obras la capilla mayor y que para su mejor hechura convendría deshacer el crucero, de ladrillo, y hacerlo como corresponde 
El aspecto de aquel templo que frecuentó Luis de Acuña, sólo podemos vislumbrarlo por el porte de los restos de su cabecera, recogidos en un grabado de Anton van den Wyngaerde, fechado en 1562 (fig. 1). La imagen trasmite un estado avanzado de destrucción, tras la guerra de las Comunidades, pero se ve perfectamente la mole de un ábside, muy destacado en altura, con alguna absidiola menor en el lado derecho ${ }^{70}$.

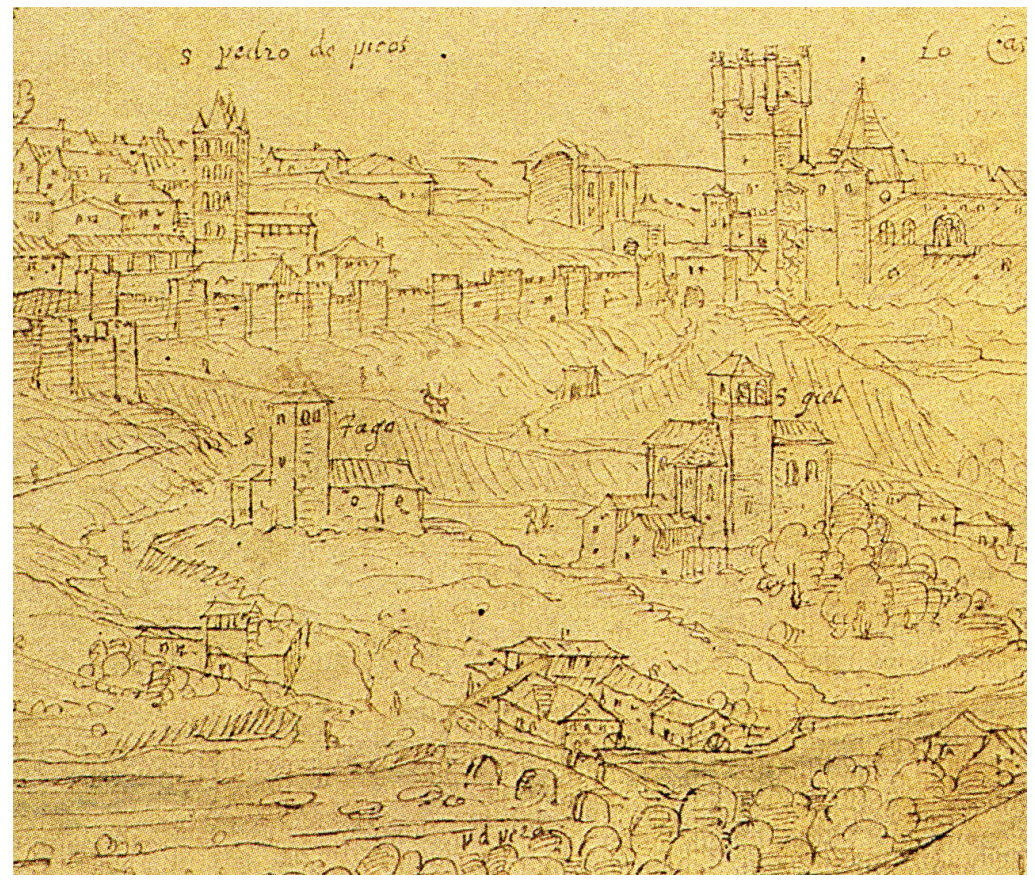

Fig. 1. Grabado de Segovia, con restos de la catedral románica, por A. van den Wyngaerde @ Museo Ashmolean, Universidad de Oxford. WA.Suth.L.4.100.1.

a la cabecera y al cuerpo de la iglesia. El prelado advirtió de la gran antigüedad y mal estado del claustro, realizado en mampostería, y hundido por muchas partes: Ruiz 1982, p. 271; 1994, pp. 162-163; Cortón 1997, p. 18; López 2006, pp. 40-41.

${ }^{70} \mathrm{El}$ núcleo catedralicio, además del claustro ya mencionado, tenía una gran torre a los pies del templo, en el lado de la epístola, que entraba en competencia con el cercano Alcázar. Por otra parte, una noticia de 1241 aludía a una cripta dedicada al Salvador y cubierta con bóvedas, pero se inutilizó por problemas que desconocemos: Ruiz 1994, p. 163; López 2006, p. 24 y 78, n. 21. Para la imagen de Wyngaerde, https://collections.ashmolean.org/collection/search/per_page/100/ offset/0/sort_by/relevance/object/37957 [consulta: 14/06/2020]. 
A esta imagen podemos añadir la descripción del canónigo Juan de Pantigoso, realizada en su Memorial de 1523. Por ese detallado texto sabemos que el edificio no era muy grande y tenía una capilla principal para albergar el altar mayor, otro altar se situaba a mano izquierda y estaba dedicado los santos Juanes, Bautista y Evangelista; por último, a la derecha, se encontraba la capilla de Santiago, que posteriormente, desde 1463, se dedicó a san Frutos ${ }^{71}$.

Del obispo Acuña nos faltan datos sobre su actuación en el templo mayor y sus dependencias, pero los trabajos de mantenimiento en el complejo catedralicio se tendrían que realizar y, aunque fuese el cabildo su impulsor, el prelado daría algún apoyo a las obras. Tenemos constancia de las dificultades y pobreza que arguye el colegio de canónigos ante el papado en los años 50 del siglo XV y tanto Nicolás V (1447-1455) como Calixto III (1455-1458) intentaron que la situación mejorase a través de la anexión e incorporación de préstamos o por medio de las tercias annatas ${ }^{72}$. En esta línea de colaboración, el 10 de junio de 1455, otra bula de Calixto III concede indulgencias a los fieles que devotamente visitaren la iglesia catedral en ciertas festividades (...) y dieren limosnas para contribuir a la construcción del claustro y del hospital. En la carta se hace alusión a la antigüedad de las construcciones, a su mal estado, pues amenazan una peligrosa y triste ruina, pero, también, a las reparaciones que ya se están haciendo, para las que se necesitan las ayudas, pues no pueden ser reparadas con las rentas de la fábrica de la catedral, porque son muy pequeñas ${ }^{73}$.

Del prelado no se dice nada en toda esta búsqueda de soluciones, pero es indudable que sin su beneplácito no se habrían conseguido las bulas romanas, cuya solicitud muy bien pudo salir de la cancillería episcopal, pues desde julio de 1454 ya era obispo consagrado, no sólo administrador. Por otra parte, es lógico pensar que la mesa episcopal cooperase a los arreglos en curso.

Aunque todavía nos faltan datos efectivos, pues los libros de fábrica que contienen detallados informes solo se conservan desde 1458, es

\footnotetext{
${ }^{71}$ Lecea 1889, pp. 216-217, 219, 225, 226, 244. Además de este memorial, existe otro del canónigo Juan Rodríguez, donde se mencionan las destrucciones sufridas por la catedral durante la guerra de las comunidades, pero únicamente se hace alusión, respecto al edificio antiguo, a las piezas que se trasladaron desde allí al nuevo asentamiento de la sede, como fueron la sillería del coro, el claustro, ciertas rejas, campanas, retablos e imágenes, pero no se habla con detalle del edificio en sí, véase Díaz-Miguel 1968, pp. 215-229.

${ }^{72}$ Sanz 1988, docs. 353, 354, 355, 357, 364, 365, 367, 373.

${ }^{73}$ Sanz 1988, doc. 371. Las fiestas aludidas eran: la Asunción de la Virgen, san Juan, Santiago y el 16 de julio, día de la consagración de dicho templo, coincidiendo con las advocaciones de los altares de la cabecera.
} 
indudable que todos los esfuerzos del joven Acuña, en relación con la organización de la sede y las relaciones obispo-cabildo, tuvieron que dar sus frutos. Lo lamentable es que fueron sus sucesores los que se llevaron todo el mérito de la ejecución de los proyectos realizados en el centro catedralicio. Así, Fernando López de Villaescusa (1457-1460) y Juan Arias Dávila (1461-1497), a pesar de los tiempos turbulentos que les tocó vivir, emprendieron destacadas obras en las que también se involucró Enrique IV (14541474), quien propuso cambiar la sede de emplazamiento, como se llevará a cabo más tarde ${ }^{74}$. Parece claro que los apoyos del papado, las indulgencias y las cuentas saneadas ponen las bases de lo que pudo hacerse tras el traslado del prelado a Burgos; es muy posible que la labor de don Luis fuera la más callada, pero no la menos importante, y en estas lides ensayase lo que muy pronto haría efectivo en su siguiente destino de forma mucho más evidente. A pesar de todo, sus apoyos continuaron desde la lejanía, pues facilitó la petición de ayudas para las obras catedralicias, a través de los arciprestazgos burgaleses, a cambio de indulgencias ${ }^{75}$.

Por otra parte, la villa episcopal de Turégano, que había sido sede de la Audiencia y Cancillería del Reino hasta 1442, contaba con un castillopalacio que continuó utilizando el obispo Acuña. Ya hemos aludido a que la casa sirvió de refugio al marqués de Villena, su pariente, en 1450; además, como señal inequívoca de la estancia del prelado, aquí firmó los documentos alusivos a los conflictivos límites de la localidad con el Concejo de Segovia. No obstante, tampoco se han podido documentar las obras de acondicionamiento del palacio, que, sin duda, debió llevar a cabo, y que también serían un antecedente de las que posteriormente realizaría en Rabé de las Calzadas ${ }^{76}$.

Las señales de ayuda del prelado, que se han podido rastrear, en el sentido de mejorar la falta de ornamentos que tenía la sede, como había atestiguado su predecesor, se documentaron en 1459, en su testamento de 1495 y en un inventario fechado en 1515. En el primer caso, se mencionan las almáticas que dio el obispo de Burgos, para las que se compró una banda de 475 maravedís. Es muy posible que estas piezas, donde figurarían

${ }^{74}$ Para los asuntos enunciados, véanse Lecea 1889, pp. 217-218; Sanz 1967, pp. 185-189; López 2001, pp. 197-198; Suárez 2003, pp. 301-327; Asenjo 2008, pp. 190-191; Nieto 2008, pp. 221-230; López, Juárez 2014, doc. 43.

${ }^{75}$ ACSg, Libro de Cuentas 1458-1475, C-201, f. 193v.

${ }^{76}$ Borreguero 1991, pp. 76-78, 86, 138; Ruiz 2006, pp. 1743-1764; Bermúdez, Marqués 2016, pp. 255, 262. El obispo don Juan Arias firmó, en 1471, con los vecinos de Veganzones y Turégano el acuerdo para reedificar la fortaleza, tras los desperfectos ocasionados por los altercados de los años 60. Los trabajos, que fueron continuados por sus sucesores, siguieron dicho proyecto, véase Barbado 1997, pp. 9, 34, 43. 
las armas del prelado, y, por ello, se le siguieron adjudicando sin dudar, formasen un terno destacado junto a una de las capas que se cita en la misma fuente. La dotación de este tipo de vestimentas ricas a la catedral es señal del interés por la magnificencia de la liturgia y la perduración de la memoria del donante; asuntos que no olvidaría, como hemos señalado, en su siguiente etapa ${ }^{77}$. La segunda referencia es la manda testamentaria de 200.000 maravedís para la Iglesia Mayor de Segovia, con el fin de que la utilizasen en ornamentos o lo más necesario que viere el cabildo, de nuevo, la intención del obispo de enriquecer el ajuar de su primera sede está muy presente, aunque, en realidad, solo recibieron dos castellanos, es decir, 970 maravedís, debido a las deudas que se tenían que sustraer de la primera can$\operatorname{tidad}^{78}$. Dicho débito, 199.030 maravedís, nos informa de gastos a cuenta del obispo, pero no podemos adjudicarlos, con seguridad, a asuntos concretos de patrocinio. Por último, en el inventario, de principios del siglo XVI, aparecen mencionadas un total de doce capas, cinco de terciopelo rojo, cinco de damasco blanco y dos de raso blanco, todas ellas con las armas de Acuña y ornadas con escenas de ángeles y apóstoles. Además, en los capillos se había bordado la figura de la Virgen María ${ }^{79}$.

Resulta sorprendente, por otra parte, que el mitrado no haya dejado vestigios de su interés por los libros en esta diócesis, dada la nutrida biblioteca que tenía al morir en 1495, aunque es muy posible que textos de su propiedad lo acompañasen a Burgos, sin dejar huella ${ }^{80}$.

${ }^{77}$ La primera noticia es del 23 de julio de 1459, en ella se especificó que se compraron, por 950 maravedís, dos bandas, una para cenefas de las dos capas verdes y otra para poner en las dalmáticas del obispo: ACSg, Libro de Cuentas 1458-1475, C-201, f. 85v; Teijeira 2021.

${ }^{78}$ En el testamento se advirtió que, si se debía algo a Rodrigo Cervantes, hermano de su antecesor en Segovia, Juan Cervantes, se le pagase de esos 200.000 maravedís: López 1961, p. 314. El canónigo Santander viajó a Burgos, comisionado por el cabildo segoviano, en 1497, para recoger lo que dejó el señor obispo, y le dieron 970 maravedís: López 2006, p. 29.

${ }^{79}$ ACSg, D-1295, ff. 32v, 33r-v; Teijeira 2021.

${ }^{80}$ En el catálogo de manuscritos medievales de la catedral segoviana no aparece ninguno, adscrito o con los blasones, de don Luis de Acuña: Janini 1963, pp. 293-321. 


\section{CONCLUSIONES}

Las actuaciones del obispo Acuña, a lo largo de su carrera eclesiástica, pueden entenderse de modo concatenado. Así, en la primera fase de su trayectoria, nos dejó señales sutiles, pero evidentes, de una preparación para las intervenciones en la organización del episcopado y la promoción artística que, posteriormente, darán frutos ostensibles.

$\mathrm{Su}$ llegada a Segovia siendo muy joven, con 23 años, y con unos medios de vida que dependían de la corte y de una diócesis modesta, no le facilitaban los recursos para emprender labores artísticas de gran envergadura. Por todo ello, sus fuerzas se centraron en labores calladas, pero de gran calado, tales como: sanear las cuentas, obtener nuevos beneficios, buscar la ayuda del papado, ordenar las relaciones con el cabildo -sin enfrentamientos-y preparar el camino para que, con una economía favorable y todos los regidores de la sede de acuerdo, se pudiesen acometer las obras de actualización del centro catedralicio, como así llevaron a cabo sus sucesores, contando -incluso- con su ayuda desde Burgos, a pesar de las turbulencias políticas por las que estaban pasando. Además, su tarea patrocinadora fue muy patente, centrada en mejorar, con un buen número de piezas ricas, las vestimentas litúrgicas, y esto podríamos relacionarlo con las donaciones de su hermana Inés a la catedral de Palencia, que, como hemos dicho, la enriqueció con capas de damasco blanco; la vinculación de la familia con el esplendor de las catedrales castellanas es indudable y se incrementará en la siguiente fase vital del prelado. En la caput Castellae, donde contó con más medios materiales y humanos, incluyendo la ayuda de la ciudad, hará más palpable, como ya hemos enumerado, lo que sigilosamente inició en Segovia. Para ello, volvió a insistir en la puesta al día de las normas que debían regir la Sede, llegando a acuerdos difíciles de pactar con el cabildo, perseveró en la mejora del ornato de la catedral y sus ajuares, sin olvidar las intervenciones en los palacios episcopales, y culminó sus aportaciones con la creación de la una capilla funeraria muy rica.

\section{BIBLIOGRAFÍA CITADA}

Agúndez San Miguel, Leticia (2014), Carreras eclesiásticas y redes clientelares en la Castilla bajomedieval: la provisión de beneficios menores en el cabildo de la catedral de Burgos (1456-1470), "Anuario de Estudios Medievales" 44/2, pp. 665-687.

Andrés Ordax, Salvador (2008), El otoño de la Edad Media. La catedral de Burgos en el siglo XV, en Payo Hernanz, René (coord.), La catedral de Burgos. Ocho siglos de Historia y Arte, Burgos, Promecal, pp. 218-265. 
Ara Gil, Clementina Julia (1987), El taller palentino del entallador Alonso del Portillo (1460-1506), “Boletín del Seminario de Estudios de Arte y Arqueología" 53, pp. 211-242.

Ara Gil, Clementina Julia (2001), Escultura en Castilla y León en la época de Gil de Siloe. Estado de la cuestión, en Actas del Congreso Internacional sobre Gil de Siloe y la Escultura de su época, Burgos, Institución Fernán González - Real Academia Burgense de Historia y Bellas Artes, pp. 145-188.

Asenjo González, María (2008), La colaboración de las ciudades en la estabilidad política del reino (1250-1520), en Nieto Soria, José Manuel; López-Cordón, María Victoria (eds.), Gobernar en tiempos de crisis: las quiebras dinásticas en el ámbito hispánico, 1250-1808, Madrid, Sílex, pp. 175-197.

Atienza López, Ángela (2008), Tiempos de conventos: una historia social de las fundaciones en la España moderna, Madrid, Marcial Pons Historia.

Bango García, Clara (2001), Estatua Relicario de Santiago el Mayor, en Bango Torviso, Isidro Gonzalo (dir.), Maravillas de la España medieval. Tesoro sagrado y monarquía, Valladolid, Junta de Castilla y León.

Baquero Moreno, Humberto (1973), Alguns acordos de Extradição entre Portugal e Castela nos seculos XIII e XIV, "Portugaliae Histórica" 1, pp. 85-87.

Barbado Esteban, Miguel (coord.) (1997), Segovia en el siglo XV. Arias Dávila: Obispo y Mecenas, Madrid, Fundación Lázaro Galdiano.

Bartolomé Herrero, Bonifacio (1996), El señorío temporal de los obispos de Segovia en la Edad Media, "Anuario de Estudios Medievales" 26/1, pp. 190-219.

Bartolomé Martínez, Bernabé (coord.) (2004), Historia de las diócesis españolas, 20. Iglesias de Burgos, Osma-Soria, Santander, Madrid, Biblioteca de Autores Cristianos.

Barrio Gozalo, Maximiliano (2004), La Iglesia de Segovia, en Egido, Teófanes (coord.), Historia de las diócesis españolas, 19. Iglesias de Palencia, Valladolid y Segovia, Madrid, Biblioteca de Autores Cristianos, pp. 383-616.

Barrón García, Aurelio Ángel (1998), La época dorada de la platería burgalesa 1400-1600, vol. I, Salamanca, Excelentísima Diputación de Burgos - Junta de Castilla y León.

Beltrán de Heredia, Vicente (1970-1971), Bulario de la Universidad de Salamanca (1219-1549), Salamanca, Universidad de Salamanca.

Beltrán de Heredia, Vicente (1971-1973), Cartulario de la Universidad de Salamanca, Salamanca, Universidad de Salamanca. 
Bermúdez Médel, Alejandro; Marqués Martín, Isabel (2016), Análisis arqueológico de la arquitectura del castillo de Turégano (Segovia, España), “Oppidum. Cuadernos de Investigación" 12, pp. 245-276.

Bertrán i Roigé, Prim (1981), Catálogo del Archivo del Colegio de España, Bolonia, Real Colegio de España.

Borreguero Virseda, Victoriano (1991), El señorío episcopal de Turégano, Segovia, Caja Segovia - Obra Social y Cultural.

Cañas Gálvez, Francisco de Paula (2012), Burocracia y cancillería en la Corte de Juan II de Castilla (1406-1454). Estudio institucional y prosoprográfico, Salamanca, Universidad de Salamanca.

Castro Sánchez, Marcial de (2000), Historia de Abarca, Palencia, Institución Tello Téllez de Meneses.

Cendón Fernández, Marta (2008), Arte y poder episcopal en la Castilla de los Trastamara, "e-Spania" [en línea], https://doi.org/10.4000/e-spania. 124 [consulta: 22/01/2020].

Colmenares, Diego (1846), Historia de la insigne ciudad de Segovia y compendio de las historias de Castilla, vol. II, Segovia, Eduardo Baeza.

Cortón de las Heras, María Teresa (1997), La construcción de la Catedral de Segovia (1525-1607), Segovia, Caja Segovia - Obra Social y Cultural.

Díaz Ibáñez, Jorge (2013a), Los eclesiásticos castellanos en los enfrentamientos urbanos (siglos XIV-XV), en Arranz, Ana; Rábade Obradó, Pilar; Villarroel, Óscar (coords.), Guerra y Paz en la Edad Media, Madrid, Sílex, pp. 141-162.

Díaz Ibáñez, Jorge (2013b), Ritualidad y cultura del consenso en la iglesia castellana bajomedieval, en Nieto Soria, José Manuel; Villarroel González, Óscar, (coords.), Pacto y consenso en la cultura política peninsular. Siglos XI-XV, Madrid, Sílex, pp. 169-204.

Díaz Ibáñez, Jorge (2015), El arzobispo Alfonso Carrillo de Acuña (1412-1482). Una revisión historiográfica, "Medievalismo" 25, pp. 135-196.

Díaz-Miguel, María Dolores (1968), Relación de Juan Rodríguez, Fabriquero mayor de la catedral de Segovia: 1523, "Estudios Segovianos" 20, pp. 215-229.

Eubel, Konrad (1914), Hierarchia Catholica Medii Aevi sive Summorum Pontificum, S. R. E. Cardinalum Ecclesiarum Antistitum Series. AB. Anno 1431 usque ad Annum 1503 Perducta, vol. II, Monasterii, Sumptibus et typis Librariae Regensburgianae.

Flórez, Enrique (1860), España Sagrada, vol. VIII, Madrid, Real Academia de la Historia - Imprenta José Rodríguez.

Francia Lorenzo, Santiago (1989a), Archivo capitular de Palencia. Catálogo, serie II, volumen I. Actas capitulares (1413-1467), Palencia, Institución Tello Téllez de Meneses. 
Francia Lorenzo, Santiago (1989b), Archivo capitular de Palencia. Catálogo, serie II, volumen II. Actas capitulares (1468-1500) e indices, Palencia, Institución Tello Téllez de Meneses.

Franco Silva, Alfonso (2014), El arzobispo de Toledo, Alonso Carrillo. Un prelado belicoso del siglo XV, apasionado por la riqueza y el poder, Cádiz, Universidad de Cádiz.

García García, Antonio (dir.) (1993), Synodicum Hispanum, IV, Ávila y Segovia, Madrid, Biblioteca de Autores Cristianos.

García García, Antonio (dir.) (1997), Synodicum Hispanum, VII, Burgos y Palencia, Madrid, Biblioteca de Autores Cristianos.

García Mercadal, José, (1999), Viajes de extranjeros por España y Portugal, Valladolid, Junta de Castilla y León.

García y García-Estévez, Ángel (1998), Episcopologio de la diócesis de Segovia. Noticias de los obispos de Segovia desde sus orígenes hasta nuestros días, "Estudios Segovianos" 40, pp. 177-345.

Gómez Bárcena, María Jesús (1994), ¿San Eustaquio o San Huberto? Un santo cazador en el retablo del árbol de Jesé en la capilla del obispo Acuña de la catedral de Burgos, "Anales de Historia del Arte" 4, pp. 419-430.

Guijarro González, Susana (2018), Las escuelas de gramática en la Castilla bajomedieval (siglos XIII-XV), "Studia Histórica. Historia Medieval" 36/2, pp. 9-38.

Janini, José (1963), Códices litúrgicos de la catedral de Segovia, "Estudios Segovianos" 15, pp. 293-321.

Ladero Quesada, Miguel Ángel (2008), El control de los recursos financieros y militares en las crisis sucesorias de la corona de Castilla. 12821479, en Nieto Soria, José Manuel; López-Cordón, María Victoria (eds.), Gobernar en tiempos de crisis: las quiebras dinásticas en el ámbito hispánico, 1250-1808, Madrid, Sílex, pp. 79-89.

Lecea, Carlos de (1889), Memorial histórico de Segovia, escrito por don Juan de Pantigoso en 1523, "Boletín de la Real Academia de la Historia" 14, pp. 212-261,

Lopes, Fernão (1966), Crónica do Senhor rei dom Fernando nono rei destes regnos, Porto, Livraria Civilização.

Lopes, Fernão (1973), Crónica del rei Dom João I da boa memoria, Lisboa, Braamcamp Freire.

López, María (2001), La fortaleza de la antigua catedral de Santa María la Mayor en Segovia, "Estudios Segovianos" 44, pp. 193-205.

López Díez, María (2006), Los Trastámara en Segovia. Juan Guas, maestro de obras reales, Segovia, Caja Segovia - Obra Social y Cultural. 
López Martínez, Nicolás (1960), La biblioteca de Don Luis de Acuña en 1496, "Hispania, XX" 78, pp. 61-110.

López Martínez, Nicolás (1961), Don Luis de Acuña, el cabildo de Burgos y la reforma (1456-1495), "Burgense" 2, pp. 185-317.

López Martínez, Nicolás (1966), Sínodos Burgaleses del siglo XV, "Burgense" 7, pp. 201-406.

López Mata, Teófilo (1966), La catedral de Burgos, Burgos, Hijos de S. Rodríguez.

López-Mayán, Mercedes (2012), El pontifical de Luis de Acuña y la iluminación de manuscritos en la Castilla de finales del siglo XV, "Anales de Historia del Arte" 22, pp. 317-331.

López-Mayán, Mercedes (2019), Identidad y memoria en los pontificales iluminados en Castilla durante la Edad Media, en Boto, Gerardo; Escandell, Isabel; Lozano, Esther (eds.), The Memory of the Bishop in Medieval Cathedrals. Ceremonies and Visualizations, Berna, Peter Lang, pp. 347-380.

López Villalba, José Miguel; Juárez Valero, Eduardo (2014), Documentación medieval segoviana. Colección diplomática del archivo de la diócesis segoviana, Segovia, Diputación Provincial.

López Villalba, José Miguel; Juárez Valero, Eduardo (2018), Colección diplomática regia en pergamino del Archivo de la catedral de Segovia, Segovia, Diputación Provincial.

Mansilla, Demetrio (1952), Catálogo de los códices de la catedral de Burgos, Madrid, Instituto Enrique Flórez - CSIC.

Marcos Rodríguez, Florencio (1962), Catálogo de Documentos del Archivo Catedralicio de Salamanca (siglos XII-XV), Salamanca, CSIC.

Martínez, Rafael (2011), La lenta construcción de un gran templo. La catedral en la época gótica, en Martínez, Rafael; Payo, René (coords.), La catedral de Palencia. Catorce siglos de Historia y Arte, Burgos, Promecal, pp. 202-288.

Martínez Sanz, Manuel (1866), Historia del templo catedral de Burgos: escrita con arreglo a documentos de su archivo, Burgos, Imprenta Anselmo Revilla.

Martínez Sanz, Manuel (1874), Episcopologio de Burgos, "Boletín eclesiástico del arzobispado de Burgos" 17, pp. 171-175.

Mattoso, José (1985), Ricos-homens infanções e cavaleiro: a nobreza medieval portuguesa nos séculos XI e XII, Lisboa, Guimarães Editores.

Menéndez González, Nicolás (2009), Juan de Colonia y los inicios del tardogótico burgalés, en Actas-IV Simposio Internacional de Jóvenes Medievalistas, Murcia, Ayuntamiento de Lorca - Universidad de Murcia. 
Menéndez González, Nicolás (2010), Juan De Colonia and the West Façade of Burgos Cathedral: 1442-1458, "Hortus Artium Medievalium"16, pp. 333-340.

Miñano, Sebastián (1827), Diccionario Geográfico-estadístico de España y Portugal, vol. VII, Madrid, Imprenta de Pierart-Peralta.

Morais, Cristóvao; Vasconcelos, Alexandre; Freitas, Eugénio; Cruz, Antonio (1943), Pedatura Lusitana. Nobiliario de familias de Portugal, vol. III-1, Porto, Fernando Machado.

Negro Cobo, Marta (2008), La riqueza de una basílica. El Museo y las Colecciones de la Catedral de Burgos, en Payo Hernanz, René (coord.), La catedral de Burgos. Ocho siglos de Historia y Arte, Burgos, Promecal, pp. 436-509.

Nieto Soria, José Manuel (1993), Iglesia y génesis del estado moderno en Castilla (1369-1480), Madrid, Universidad Complutense.

Nieto Soria, José Manuel (2008), Iglesia y crisis dinásticas en la Castilla bajomedieval, en Nieto Soria, José Manuel; López-Cordón, María Victoria (eds.), Gobernar en tiempos de crisis: las quiebras dinásticas en el ámbito hispánico, 1250-1808, Madrid, Sílex, pp. 221-234.

Olivares Martínez, Diana (2013), Alonso de Burgos y la arquitectura castellana en el siglo $X V$, Madrid, La Ergástula.

Oliveira Serrano, César (2013), Portugal y Castilla entre la paz y la guerra en el siglo XV, en Arranz, Ana; Rábade, María del Pilar; Villarroel, Óscar (coords.), Guerra y Paz en la Edad Media, Madrid, Sílex, pp. 375-400.

Pampliega Pampliega, Rafael (2005), Pontido y otras dependencias de la catedral de Burgos, Burgos, Monte Carmelo.

Payo Hernanz, René (coord.) (2008), La catedral de Burgos. Ocho siglos de Historia y Arte, Burgos, Promecal.

Payo Hernanz, René; Matesanz del Barrio, José (2013), El cimborrio de la Catedral de Burgos: historia, imagen y símbolo, Burgos, Real Academia Burgense de Historia y Bellas Artes - Institución Fernán González.

Payo, René; Martín Martínez de Simón, Elena (2018), Alonso de Cartagena: política, religión y mecenazgo en la Castilla de mediados del siglo $X V$, en Herráez Ortega; Cosmen Alonso, María Concepción; Teijeira Pablos, María Dolores; Moráis Morán, José Alberto (eds.), Obispos y catedrales. Arte en la Castilla bajomedieval, Berna, Peter Lang, pp. 121-162.

Pazos López, Ángel (2018), Vestidos de pontifical. La iconografía de las insignias litúrgicas episcopales en la Castilla bajomedieval, en Herráez Ortega, María Victoria; Cosmen Alonso, María Concepción; 
Teijeira Pablos, María Dolores; Moráis Morán, José Alberto (eds.), Obispos y catedrales. Arte en la Castilla bajomedieval, Berna, Peter Lang, pp. 355-376.

Pimenta Ferro Tavares, Maria José (1983), A nobreza no reinado de dom Fernando e a sua actuação em 1383-1385, "Revista de História Económica e Social" 12, pp. 45-89.

Quintanilla, Mariano (1954), Concordia entre el obispo y el cabildo, "Estudios Segovianos" 6, pp. 320-327.

Réau, Louis (1997), Iconografía del arte cristiano. Iconografia de los santos: de la $G$ a la $O$, Madrid, Ediciones del Serbal.

Rodríguez Montañés, José Manuel (coord.) (2002), Rabé de las Calzadas, en Enciclopedia del románico en Castilla y León. Burgos, vol. II, Aguilar de Campoo, Fundación Santa María La Real, pp. 721-723.

Romero Portilla, Paz (2002), Exiliados en Castilla en la segunda mitad del siglo XIV. Origen del Partido Portugués, en Poder y sociedad en la Baja Edad Media hispánica. Estudios homenaje al profesor Luis Vicente Díaz Martín, vol. I, Valladolid, Universidad, pp. 519-539.

Rosell, Cayetano (coord.) (1875-1878), Crónicas de los Reyes de Castilla, desde don Alfonso el Sabio hasta los católicos don Fernando y doña Isabel, Madrid, Ribadeneyra.

Ruiz de Vergara y Álava, Francisco (1661), Vida del ilustrísimo don Diego de Anaya y Maldonado arzobispo de Sevilla, fundador del Colegio Viejo de San Bartolomé, Madrid, Diego Díaz de la Carrera.

Ruiz Hernando, José Antonio (1973), La arquitectura civil de estilo románico en Segovia, "Estudios Segovianos" 25, pp. 91-93

Ruiz Hernando, José Antonio (1982), Historia del urbanismo en la ciudad de Segovia del siglo XII al XIX, Segovia, Diputación Provincial.

Ruiz Hernando, José Antonio (1990), La catedral en la ciudad medieval, en Gutiérrez Robledo, José Luis (coord.), Medievalismo y neomedievalismo en la arquitectura española. Salamanca, Universidad de Salamanca, pp. 81-114.

Ruiz Hernando, José Antonio (1994), La catedral de Segovia, en Navascués Palacio, Pedro; Gutiérrez Robledo, José Luis (dirs.), Medievalismo y neomedievalismo en la arquitectura española: Las catedrales de Castilla y León, vol. I, Ávila, Fundación Cultural Santa Teresa, pp. 161-192.

Ruiz Hernando, José Antonio; Rodríguez Montañés, José Manuel (coords.) (2006), Segovia y Turégano, en Enciclopedia del románico en Castilla y León. Segovia, vol. III, Aguilar de Campoo, Fundación Santa María la Real, pp. 1349-1360, 1743-1764. 
Salvador Miguel, Nicasio (2008a), El divorcio del príncipe don Enrique de Castilla y doña Blanca de Navarra (1453), en Salvador Miguel, Nicasio; Moya García, Cristina (eds.), Literatura en la época de los Reyes católicos, Madrid, Vervuert - Editorial Iberoamericana, pp. 249-274.

Salvador Miguel, Nicasio (2008b), Isabel la Católica. Educación, mecenazgo y entorno literario, Alcalá de Henares, Centro de Estudios Cervantinos.

Santamaría Lancho, Miguel (1990), El cabildo catedralicio de Segovia como aparato de poder en el sistema político urbano durante el siglo XV, "Studia Histórica (Historia Medieval)" 8, pp. 47-77.

Sanz y Sanz, Hilario (1967), Bosquejo histórico de dos catedrales, "Estudios Segovianos" 19, pp. 161-204.

Sanz y Sanz, Hilario (1988), Catálogo de la colección diplomática medieval (1115/1500) del archivo catedralicio de Segovia, Segovia, Caja Segovia - Obra Social y Cultural.

Serna Serna, Sonia (2008), Los obituarios de la catedral de Burgos, León, Centro de Estudios e Investigación "San Isidoro".

Sotto Mayor Pizarro, José Augusto de (1999), Linhagens medievais portugueses. Genealogias e estratégias (1279-1325), Porto, Centro de Estudos de Genealogia, Heráldica e História da Família, Universidade Moderna.

Suárez Fernández, Luis (2003), Nobleza y Monarquía: entendimiento y rivalidad. El proceso de construcción de la corona española, Madrid, La Esfera de los Libros.

Teijeira Pablos, María Dolores (2021), Una mirada al "muy menguado" vestuario de la catedral de Segovia. Capas, casullas, dalmáticas y otras vestiduras litúrgicas de obispos y capitulares (1459-1472), en prensa.

Úzquiza Ruiz, Teodoro (2017), Los misales y los pasionarios burgenses, "Burgense" 58/1, pp. 209-238.

Vasallo Toranzo, Luis (2018), Imágenes para la devoción de los poderosos. Diego de Siloe al servicio del obispo Juan Rodríguez de Fonseca y el contador Cristóbal Suárez, "De Arte" 17, pp. 7-23.

Vicente Baz, Raúl (2008), Los libros de Actas capitulares de la Catedral de Salamanca (1298-1489), Salamanca, Cabildo Catedral de Salamanca.

Villarroel González, Óscar (2010) Eclesiásticos en la diplomacia castellana del siglo XV, "Anuario de Estudios Medievales" 40/2, pp. 791-819.

Villaseñor Sebastián, Fernando (2017), Las hojas donde anidan geniecillos y animaluchos: Gil de Siloe y los espacios para lo profano en la Castilla tardogótica, "Codex Aquilarensis" 33, pp. 171-198. 
Yarza Luaces, Joaquín (2000), Gil Siloe. El Retablo de la Concepción en la capilla del obispo Acuña, Burgos, Asociación Amigos de la catedral de Burgos.

Fecha de recepción del artículo: julio 2020

Fecha de aceptación y versión final: marzo 2021 